\title{
Removal of Trypanosoma cruzi by white cell-reduction filters: an electronmicroscopic study
}

\author{
Remoção de Trypanosoma cruzi através de filtros para redução de leucócitos: \\ um estudo eletromicroscópico
}

\author{
Antonio Fabron Junior, José O rlando Bordin, Hélio Moraes-Souza, \\ Edna FreyMüller and Eliana Lages-Silva
}

\begin{abstract}
White cell (WBC)-reduction filters have been shown to be effective in removing infectious agents from infected blood products. In this study, the mechanisms of Trypanosoma cruzi (T. cruzi) retention by WBC-reduction filters were assessed. Human packed red blood cell $(P R B C)$ and platelet concentrate $(P C)$ samples were contaminated with T. cruzi organisms ( $Y$ strain; $3.4 \times 106 / \mathrm{ml}$ ), and then filtered using WBC-reduction experimental filters that provided about $3 \log _{10}$ WBC removal. Transmission electron microscopy sections showed that $\mathrm{T}$. cruzi parasites were removed from contaminated PRBC and PC samples primarily by mechanical mechanism without interacting with filter fibbers or blood cells. In addition, we found that T. cruzi parasites were also removed by a direct fibber adhesion. These data indicate that $\mathrm{T}$. cruzi parasites are removed from infected blood not only by mechanical mechanism but also by biological mechanism probably mediated by parasite surface proteins.
\end{abstract}

Key-words: Chagas' disease. White cell-reduction filter. Blood filtration. Electron microscopy.

Resumo Os filtros de leucócitos são eficazes em remover agentes infecciosos de hemocomponentes infectados. Neste estudo, foram avaliados os mecanismos de retenção de Trypanosoma cruzi (T. cruzi) por filtros de leucócitos. Amostras de concentrado de glóbulos vermelhos (CGV) e concentrado de plaquetas (CP) foram contaminados com parasitas T. cruzi (cepa Y, 3,4 x 106/ml), e filtrados com filtros experimentais de leucócitos, com capacidade de remoção de aproximadamente $3 \log _{10}$ leucócitos. $A$ análise das fibras dos filtros através de microscopia eletrônica de transmissão mostrou que os parasitas $\mathrm{T}$. cruzi foram removidos dos CGV e CP contaminados por mecanismo físico, sem interação com células sangüíneas. Além disso, foi demonstrado que os parasitas T. cruzi foram também removidos por adesão direta às fibras dos filtros, sugerindo um mecanismo biológico, provavelmente mediado por proteínas da superfície do parasita.

Palavras-chaves: Doença de Chagas. Filtros de leucócitos. Filtração de sangue. Microscopia eletrônica.

\footnotetext{
Escola Paulista de Medicina da Universidade Federal de São Paulo, São Paulo, SP, Faculdade de Medicina do Triângulo Mineiro, Uberaba, MG e Faculdade de Medicina de Marília, Marília, SP, Brasil.

This work was partly supported by the Conselho Nacional de Desenvolvimento Científico e Tecnológico (CNPq, Brazil).

Address to: Dr. Antonio Fabrron Junior. Disciplina de Hematologia e Hemoterapia da Faculdade de Medicina de Marília. R. Lourival Freire 240, 17519-050 Marília, SP, Brasil.

Tel: 5514 422-6588; Fax: 5511 433-0148.

Recebido para publicação em 20/4/98
} 
Chagas' disease is a zoonosis caused by flagellate protozoan parasite Trypanosoma cruz $\beta$. The disease is widespread in Latin America where about 18 million people were infected and 90 million people were at risk in the early 90's 111820 . With the eradication, in some countries, of the blood-sucking triatome insects which transmit T. cruzi, allogeneic blood transfusions have been the main route of transmission of Chagas' disease in urban areas of both endemic and non-endemic countries 11 18. Over the post years, the problem was limited to Latin America however, with the continuous emigration of $T$. cruzi-infected people to developed countries and the report of 4 cases of transfusion-associated Chagas disease (TA-CD) in immunocompromised patients 101115 18, the risk of $T$. cruzi transmission by blood

filters from contaminated blood products.

\section{MATERIAL AND METHODS}

Blood components. Trypomastigote forms of T. cruzi ( $\mathrm{Y}$ strain) were obtain from infected blood of male swiss mice, which are routinely maintained in our laboratory. Human whole blood was collected in triple bags with CPDA-1 (Baxter Healthcare Corporation, Fewal Division, Mexico). After collection, whole blood units were immediately centrifuged for 4 minutes $(1,800 \mathrm{~g}$, $22^{\circ} \mathrm{C}$ ) and the platelet-rich plasma was transferred to the satellite bag using the heat-sealing method. The packed red blood cell (PRBC) concentrate was kept at room temperature for about 2 hours. After this short time storage, PRBC samples of $5 \mathrm{ml}$ were contaminated with $17 \times 10^{6}$ T. cruzi $\left(3.4 \times 10^{6}\right.$ per $\left.\mathrm{ml}\right)$. The parasites was mixed with red cells from PRBC by tube inversion (5x) and kept at room temperature for an extra hour, before filtration. In order to prepare platelet concentrates (PCs), platelet-rich plasma unit was centrifuged for 10 minutes $(3,560 \mathrm{~g}$, $22^{\circ} \mathrm{C}$ ) and the platelet-poor plasma unit was transferred to the satellite bag using the heatsealing method. A PC sample were kept at room temperature $\left(22^{\circ} \mathrm{C}\right)$, under orbital agitation. After a four-day storage period, PC samples $(5 \mathrm{ml})$ were contaminated with $17 \times 10^{6}$ T. cruzi $\left(3.4 \times 10^{6}\right.$ per $\mathrm{ml}$ ) and kept at room temperature for one hour, before filtration.

Enumeration of the parasites. The enumeration of $T$. cruzi parasites from contaminated mice whole blood from human PRBC and PC samples was performed before and after filtration by transfusions is increasing also in non-endemic countries. Currently, the strategies to prevent TACD include general approaches such as education and identification of putatively infectious blood donors by questionnaire; serologic tests; and in areas of high endemicity, the treatment of the collected blood with gentian violet1 71417 .

Based on the evidence that white cell (WBC)reduction filters are effective in preventing of some biologic effects caused by allogeneic blood transfusions 4 12; in removing virus and bacteria present in blood components 459 ; and, in directly removing $T$. cruzi from contaminated blood $^{13}$, the present study investigated, by electron microscopy, the possible mechanisms involved in the removal of $T$. cruzi by WBC-reduction

Brener's method6. Briefly, $5 \mu \mathrm{l}$ of contaminated contaminated samples from either mice whole blood or human blood, were spread in a slide with a $22 \times 22 \mathrm{~mm}$ cover-slip to form a single layer of blood cells. The number of trypanosomes present in the samples was investigated by scoring the parasites observed into 50 fields and by multiplying the score by 52 . The constant used in this calculation was previously estimated under a $40 x$ objective and a 10x ocular6.

Blood component filtration. The experimental WBC-reduction filters used in this study were made of cellulose acetate fibber with $5 \mathrm{ml}$ capacity and provide about $3 \log _{10}$ leukocyte removal (Miles Inc., Berkeley, CA). This filter efficacy has been previously demonstrated in experimental animal models 23 . The filtration of five samples of artificially $T$. cruzi-infected PRBC was performed by diluting the PRBC to achieve a haematocrit of 30 percent $(0,30)$ with saline. While the filtration of four samples of PC was performed directly, without diluting. The filtration through the WBCdepletion filter was made using a $5 \mathrm{ml}$ syringe. The procedure took about 1 minute.

Electron microscopic examination. Immediately after filtration, the WBC-reduction filters were opened and embedded with 2-percent glutaraldehyde in $0.1 \mathrm{M}$ sodium cacodylate for electron microscopic examination. After 1 minute in this solution, the filters were closed and kept for at least 24 hours at $4^{\circ} \mathrm{C}$. To examination by transmission electron microscopy (TEM), centre and peripheral samples of the filters were selected. We rinsed the samples in $0.1 \mathrm{M}$ sodium 
cacodylate for twice, each (15 minutes) and then kept for 12 hours at room temperature. After the incubation, the fibers were fixed with $0.1 \mathrm{M}$ osmium tetroxide for 60 minutes at room temperature. The samples were rinsed again, and dehydrated in graded alcohols (50-100\%) for 30 minutes, and in propylene oxide for 15 minutes. Subsequently, the samples were infiltrated with resin and embedded in araldite. Parts of blocks were chosem for the preparation of ultrathin sections $(70-80 \mathrm{~nm})$ and then stained with 2-percent uranila acetate in 50-percent ethanol for 5 minutes. After stained, the ultrathin sections were rinsed in graded alcohol (50-5\%) and water for 10 minutes. Thereafter, the ultrathin sections were stained with lead citrate for 1 minute and

then examined in a transmission electron microscope (JEOL, JEM-1200 EX II, Japan).

\section{RESULTS}

Parasite removal. Confirming the observations reported previously 13 , the results of the present study showed that the WBC-reduction experimental filters were partially effective in removing $T$. cruzi not only from contaminated PRBC but also from infected PC. The filtration of the contaminated PRCB samples was $40 \%$ effective, resulting in a parasite count reduction from 3.4 to $2 \times 106 / \mathrm{ml}$. The filtration of the contaminated PCs samples was $53 \%$ effective,

Tabela 1 - Number of T. cruzi parasites from contaminated human packed red blood cell and platelet concentrate before and after filtration and the percent of parasites removed by WBC-reduction filters.

\begin{tabular}{lccc}
\hline Blood component & \multicolumn{2}{c}{ Number of parasites } & Retention (\%) \\
\cline { 2 - 4 } & pré & $10 \times 10^{6}$ & 40 \\
\hline PRBC & $17 \times 10^{6}$ & $8 \times 10^{2}$ & 53 \\
PC & $17 \times 106$ & & \\
\hline
\end{tabular}

resulting in a parasite count reduction from 3.4 to $1.6 \times 106 / \mathrm{ml}$ (Tabela 1$)$.

Microscopic studies by TEM sections

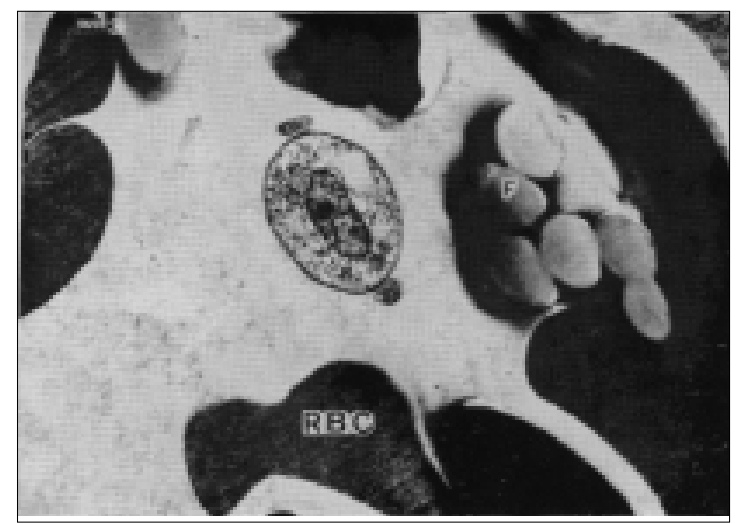

Figure 1 - Photomicrograph obtained after filtration of T. cruzi-contaminated PRBC by a WBC-reduction filter. Transmission electron microscopy showing fibers $(F)$ in cross-section, red cells (RBC), and a trypomasgigote form of T. cruzi (T). Magnification x 11.500 . showed that $T$. cruzi parasites were removed from contaminated PRBC and PCs primarily by mechanical mechanism with parasites not

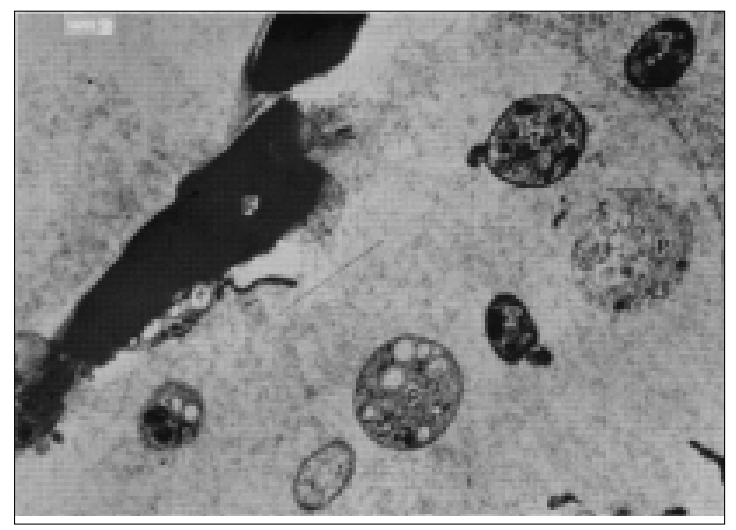

Figure 2 - Photomicrograph obtained after filtration of T. cruzi-contaminated $P C$ by a WBC-reduction filter. Transmission electron microscopy showing a fiber in cross-section $(F)$, platelets $(P)$, and trypomastigote forms of T. cruzi (T). Magnification x 11.500 . 
interacting neither with fibers nor with blood cells (Figures 1 and 2). However, in an additional experiment showed that a T. cruzi parasite from contaminated PRBC was removed by a direct

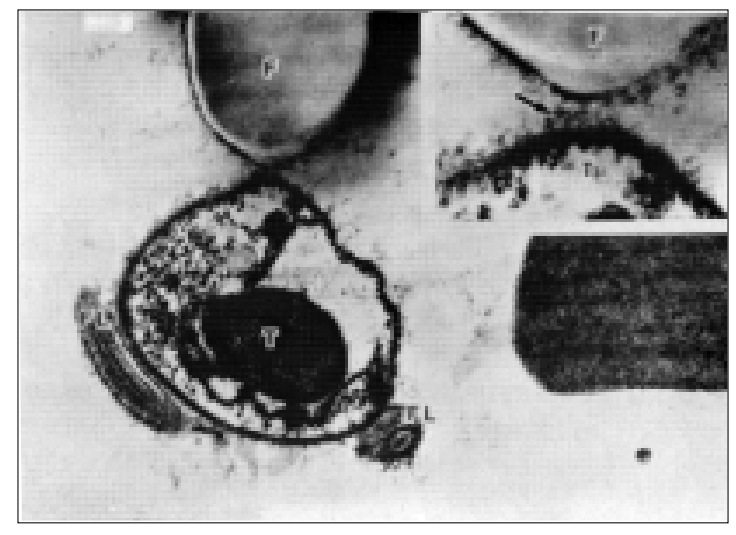

Figure 3 - Photomicrograph obtained after filtration of T. cruzi-contaminated PRBC by a WBC-reduction filter. Transmission electron microscopy showing a fiber $(F)$ in cross section, and a trypomastigote form of T. cruzi $(T)$ with a visible flagellum (FL). Magnification x 33.000. The upper right corner shows the fiber $(F)$ in close contact (arrow) with the trypomastigote form of T. cruzi $(T)$. Magnification $x 84.000$.

fiber adhesion (Figure 3), characterizing a biological mechanism of retention (parasite-fiber).

\section{DISCUSSION}

It has been recently suggested that WBCreduction filters may prevent the transmission of virus and bacteria present in blood components 9 . The retention of infectious agents by WBCreduction filters is ordinarily determinated by the type of virus and therewith the binding towards WBCs; the type of bacteria and holding period before filtration; the deformability of infected cells; and the desintegration of cells in the filter ${ }^{19}$. Two mechanisms have been proposed to explain reduced bacterial growth in WBC-reduced blood products: removal of WBCs that have phagocytosed bacteria and direct removal of bacteria by the filter itself. However, neither mechanism has been distinguished directly by studies determining bacterial localization perifiltration 9 .

Recently, we have reported the efficacy of various WBC-reduction filters in directly removing T. cruzi from contaminated blood13. To extend our previous observations, in the present study we evaluated, by electron microscopy, the possible mechanisms involved in the removal of $T$. cruzi from artificially contaminated blood components samples. Using the scoring method, it was possible to confirm that WBC-reduction experimental filters are partially effective in removing $T$. cruzi from contaminated blood components. In addition, using TEM we found that $T$. cruzi was removed from contaminated PRBC by both mechanical (barrier retention), and biological mechanisms. Probably, the fiber adhesion occurs due to surface characteristics of parasite T. cruzi. It is possible that glycoproteins present in the surface of parasite participate in the direct adhesion of the parasites to the fibbers of the filters. In this context, it was recently identified a protein with $60 \mathrm{Kd}$ (penetrin) at the surface of $T$. cruzi parasites that mediates the adhesion of the organisms to components of extra-cellular matrix, as collagen ${ }^{16}$. In the present study, we also demonstrated that $T$. cruzi parasites were removed from infected PCs by WBCreduction filters without interacting with filter fibbers or blood cells, suggesting a mechanical mechanism of retention.

In conclusion, the present data confirm that WBC-reduction filters are capable of removing T. cruzi parasites from contaminated blood components; and that the parasites retention 
occurred mainly by mechanical bur also by biological mechanisms. However, clinical studies with T. cruzi-infected persons and using WBC- reduction filters of better capacity of leukocyte reduction are necessary to ascertain the clinical efficacy of WBC-reduction filters in reducing the

transmission of parasites by allogeneic blood transfusions.

\section{ACKNOWLEDGEMENTS}

The experimental WBC-reduction filters used in this study were a kind gift of Dr. Morris A.

\section{Blajchman from McMaster University (Hamilton, ON, Canada).}

\section{REFERENCES}

1. Appleman MD, Shulman IA, Saxena S, Kirchhoff LV. Use of a questionnaire to identify potential blood donors at risk for infection with Trypanosoma cruzi. Transfusion 33:61-64, 1993

2. Blajchman MA, Bardossy L, Carmen R, Sastry A, Singal DP. Allogeneic blood transfused-induced enhancement of tumor growth: two animal models showing amelioration by leukodepletion and passive transfer using spleen cells. Blood 81:1880-1882, 1993.

3. Bordin JO, Bardossy L, Blajchman MA. Growth enhancement of established tumors by allogeneic blood transfusions in experimental animals and its amelioration by leukodepletion: The importance of the timing of the leukodepletion. Blood 84:344-348, 1994.

4. Bordin JO, Heddle NM, Blajchman MA. Biologic effects of leukocyte present in transfused cellular blood products. Blood 94:1703-1721, 1994.

5. Bowden RA, Cays M, Schooch G. Comparison of filtered blood (FB) to seronegative blood products (SB) for prevention of cytomegalovirus (CMV) infection after bone marrow transplant (abstract). Blood 82 (suppl 1):204a, 1993.

6. Brener Z. Therapeutic activity and criterion of cure on mice experimentally infected with Trypanosoma cruzi. Revista do Instituto de Medicina Tropical de São Paulo 4:389-396. 1962.

7. Carvalho MR, Krieger MA, Almeida E, Oelemann W, Shikanay-Yassuda MA, Ferreira AW, Pereira JB, SáezAlquézar A, Dorlhiac-Llcer PE, Chamone DF, Goldenberg $S$. Chagas' disease diagnosis: evaluation of several tests in blood bank screening. Transfusion 33:830-834, 1993.

8. Chagas C. Nova tripanosomiase humana. Estudos sobre a morfologia e o ciclo evolutivo do Schizotrypanum cruzi n.g., n.s.p., agente etiológico de nova entidade mórbida no homem. Memorias do Instituto Oswaldo Cruz 1:159218, 1909.

9. Goldman M, Delage G. The role of leukodepletion in the control of transfusion-transmitted disease. Transfusion Medicine Reviews 9:9-19, 1995.

10. Grant IH, Gold JVVM, Wittner M, Tanowitz HB, Nathan C,
Mayer K, Reich L, Wollner N, Steinherz L, Ghavini F, O'Reilly RJ, Armstrong D. Transfusion-associated acute Chagas' disease acquired in the United States. Annals of Internal Medicine 111:849-851, 1989.

11. Kirchhoff LV. American trypanosomiasis (Chagas' disease): A tropical disease now in the United States. New England Journal of Medicine 329:639-644, 1993.

12. Lane TA, Anderson KC, GoodnoughLT, Kurtz S, Moroff G, Pisciotto PT, Sayers M, Silberstein LE. Leukocyte reduction in blood component therapy. Annals of Internal Medicine 117:151-162, 1992.

13. Moraes-Souza H, Bordin JO, Bardossy L, MacPherson DW, Blajchman MA. Prevention of transfusion-associated Chagas' disease: Efficacy of white cell-reduction filters in removing Trypanosoma cruzi from infected blood. Tranfusion 35:723-726, 1995.

14. Moraes-Souza H, Bordin JO. Strategies to prevention of transfusion-associated Chagas' disease. Transfusion Medicine Reviews 10:161-170, 1996.

15. Nickerson P, Orr P, Schroeder ML, Sekla L, Johnston JB. Transfusion-associated Trypanosoma cruzi infection in a non-endemic area. Annals of Internal Medicine 111:851853, 1989.

16. Ortega-Barria E, Pereira MEA. A novel T. cruzi heparin binding protein promotes fibroblast adhesion and penetration of engineered bacteria and Trypanosomes into mammalian cells. Cell 67:411-421, 1991.

17. Ramirez LE, Lages-Silva E, Pianetti GM, Rabelo RCM, Bordin JO, Moraes-Souza H. Prevention of transfusionassociated Chagas' disease by sterilization of $T$. cruziinfected blood with gentian violet, ascorbic acid and ligth. Transfusion 35:226-230, 1995.

18. Schmuñis GA. Trypanosoma cruzi, the etiologic agent of Chagas'disease: status in the blood supplying endemic and nonendemic countries. Transfusion 31:547-557, 1991.

19. Steneker I, Pietersz RN, Reesink HW. Leukocyte filtration mechanisms. Factors influencing the removal of infectious agents from red cell concentrates. Immunology Investigation 24:87-93, 1995.

20. Wendel S, Gonzaga AL. Chagas' disease and blood transfusion: a new world problem? Vox Sanguinis 64:1- 